\title{
Students and Teachers' Perceptions on English Online Teaching-Learning in Sumbawa Island during Covid-19: Challenges and Strategies
}

\author{
Suciaty Ramdhani*, Muhammad Azhar Kholidi \\ Postgraduate Program of TESL, Faculty of Education, \\ Universiti Teknologi MARA, Malaysia \\ *Corresponding Author. Email: 2020293304@student.uitm.edu.my
}

\begin{abstract}
This study aims at examining students and teachers' perceptions on problems and solutions in online English classrooms during Covid-19 outbreak. This qualitative study reports of four students and four teachers purposefully selected in five junior high schools in Sumbawa Island, West Nusa Tenggara, Indonesia. The data are collected through semi-formal interview. Open coding technique is used for analyzing the text data manually. The findings showed that both the students and the teachers mostly faced internet data and connectivity issues. The teachers also experienced challenges in technology utility and pedagogical aspects such as teaching method and time management, while the students have also struggled in processing the learning input and sometimes were less motivated. All of the participants utilized some ways to deal with internet and connectivity problems, such as finding WIFI, conducting a blendedlearning classroom, and seeking help and support from friends and colleagues. Moreover, most of the teachers recommended that the school principal or educational stakeholders take initiatives to train them in instructional technology and competency in teaching. Thus, the implementation of the online learning during the Covid-19 pandemic, especially in rural area, caused various problems for teachers and students, as well as triggered them to seek for the solutions and put their constructive wishes on the schools and educational stakeholder.
\end{abstract} Article History

Received: 03-10-2021

Revised: 17-10-2021

Accepted: 22-11-2021

Published: 11-12-2021

Key Words:

Online Classroom,

Perception,

Teaching-Learning

Strategies,

Challenges,

Covid-19.

How to Cite: Ramdhani, S., \& Kholidi, M. (2021). Students and Teachers' Perceptions on English Online Teaching-Learning in Sumbawa Island during Covid-19: Challenges and Strategies. Jurnal Kependidikan: Jurnal Hasil Penelitian dan Kajian Kepustakaan di Bidang Pendidikan, Pengajaran dan Pembelajaran, 7(4), 795-809. doi:https://doi.org/10.33394/jk.v7i4.4364

https://doi.org/10.33394/jk.v7i4.4364

This is an open-access article under the CC-BY-SA License.

\section{Introduction}

The Covid-19 pandemic has wreaked havoc on the world, affecting nearly every element of human life. The temporary closure of educational institutions worldwide is a telling example of the disruption created by Covid-19. (Heng \& Sol, 2020). Many schools close because of Covid-19. Thus, to ensure teaching sustainability, face-to-face classes have indeed been relocated virtual, entering a new age of digitisation studying in which the teachers, courses, and all academic activities are managed virtually. After the official Covid19 announcement was released in March 2020, the school activities were stopped in Indonesia, but then Indonesia decided to continue implementing online learning because there is no sign that Covid-19 will end.

Online learning is implemented with a distance learning system. Chun, Kern, and Smith (2016) defines that distance learning is an education system in which learners are separated from the educator and the learning process uses various resources through Information and Communication Technology (ICT). In the Covid-19 pandemic condition, this learning approach can be a settlement so that the teaching and learning process can continue. 
Both instructors and pupils' experience and expertise in information and communications technology (ICT) affect the achievement of the online learning. Thus, it needs e-learning devices which are essential in supporting schools in promoting learning outcomes while schools were closed (Subedi et al., 2020). Since then, teachers already use unified communication and collaboration systems such as Microsoft Teams, Google Classroom, Canvas, and Blackboard to create online courses, studying, and competence development programs (Petrie, 2020). They contain features such as chat, video call, and storage, which support sustaining classes formed and effective.

Due to online learning is something new in Indonesia, thus, it manifest various challenges of its implementation. Many educational citizens, including students and teachers, perceived that in terms of access, the challenge for the Indonesian government is when Distance Learning (PJJ) is conducted online and implemented in areas where accessibility, infrastructure and digital literacy are still low, as cited in Hamid, Seatryo, and Hassan (2020). They pointed out that the availability of supporting learning infrastructure such as the availability of stable internet access, access devices with the latest technology, devices used for internet access, as well as the presence of students who live in areas where there is no electricity network determine the success of online learning.

In some Indonesian provinces, access to learning in this Covid-19 era is somehow more challenging. A survey conducted by UNDP and UNICEF (2021) titled "Socioeconomic impact of the Covid-19 pandemic in post-disaster areas" in Central Sulawesi and West Nusa Tenggara that have experienced a 'double burden of economic losses due to earthquake disaster and the Covid-19 pandemic analysed the socioeconomic impact of the pandemic. The study found that children in disaster-hit areas bore the brunt of the pandemic, with 21.8 per cent of households with children experiencing difficulties in accessing education and health services for their children. Like other West Nusa Tenggara areas, in Sumbawa, most individual students come from rural villages where their parents are primarily illiterate farmers. Some students do not obtain devices to conduct the online class and very few teachers understand how to operate the tools of online learning platforms.

Several current studies have demonstrated students' and teachers' assessments of beneficial and undesirable aspects of online learning: Dube (2020), Towip et al. (2020), Agung et al. (2020), Heng \& Sol (2020), Khan et al. (2021). Dube (2020) had identified the problems students and teachers faced in online and teaching during the Covid-19 pandemic and offered a solution. He categorised the problems into challenges of online learning in rural areas, unavailability of the network in rural areas, shortage of devices for online learning, closure of internet cafés, lack of computer skills of some rural teachers, and expensive internet data. The studies provide some recommendations to solve the problems such as enhancing online teaching and learning in rural schools in Covid-19, social inclusive learning approach, equal access to learning resources, and providing teachers trained in online teaching and learning. This study reveals that the students required more significant assistance in terms of internet data access and technique arrangements for significant quality improvement. As a result, it suggested that education stakeholders were involved in creating infrastructures and improving virtual capabilities in students and facilitators.

Towip et al. (2020) found that students had some online learning difficulties and felt unsatisfied with online learning in the Covid-19 Pandemic. There are three challenges that students face; (1) internet data and connectivity issues, (2) a lack of organisation and time management, and (3) students who were less motivated as a result of a new learning method. Another research was done by Adedoyin \& Soykan (2020) and Heng \& Sol (2020); Covid-19 has brought many challenges for students, educators, school administration and parents, 
among other stakeholders. Their challenges are limited technological infrastructure and capacity, socioeconomic factors, a lack of experience conducting assessment and supervision in an online mode, increased workload for teachers and education staff, and incompatibility with specific subject matters or cultures.

English teaching and learning is also one of the many aspects that should adapt to the new way during the Covid-19 outbreak. According to Agung et al. (2020), most English students are unprepared for this rapid transformation in teaching and learning styles on online learning. Several reasons have been discovered, and they may be divided into three categories. The first is the availability and stability of an internet connection. According to this study, from 66 samples of university students, there were only $24.3 \%$ of students had a good signal quality, $66.7 \%$ of students had unstable signals while $9.1 \%$ went with poor signal or no signal at all. Those having poor signal were in the middle of nowhere (very remote area). The second is the accessibility of teaching media. The Internet, besides is considered the source of needed materials to achieve the goals of teaching and learning, can also be the source of most issues the students face. The unstable internet connection and enough internet data/ quota at their home really challenge the students in learning and doing the assignments. Moreover, low-end mobile phones and cost to earn online learning was the predominant factor of concern to $66.7 \%$ of students. The last is the compatibility of media access tools. It was found that $54.5 \%$ of the lecturers used Google Classroom for their teaching Platform. However, $75.8 \%$ of the students preferred WhatsApp and only $18.2 \%$ of them chose Google Classroom. Other platforms such as Zoom and Edmodo, since they require more data to connect, were not really recommended by the students; Zoom (6.1\%) and Edmodo (0\%).

Due to the prevention of further risk of learning loss, the new regulation for teaching and learning activity was emerged currently, that is Pembelajaran Tatap Muka (PTM) Terbatas or restricted face-to-face learning for some eligible regions in Indonesia. Although there are some schools that are still in full online instruction phase and some still implement shift distanced learning, mix-method between online learning and face-to-face learning suitable to the school context is needed to overcome problem the students and the teachers face in English online classes. As concluded by Moorhouse (2020) in his report on the adaptations made to one initial teacher education course that the blend between online and offline modes of instruction seem to be a possible way to support learning when face-to-face instruction is not an option. For educators, in integrating both synchronous and asynchronous learning is somehow new. Thus, some considerations to the learning condition and analysis of students' readiness are important to minimize issues encountered. Aligning synchronous and asynchronous communication to the present educational environment benefits for both facilitators and learners to offer help in "real time", for catering individuals, and for students, to have a greater participatory role in the design of the learning environment. It is an approach that both students and educators can better support the isolated learner as proposed by Gillett-Swan (2017).

Research focusing on investigating the difficulties perceived by both sides of students and teachers in a rural area has not been done much. Hence, it is crucial to investigate the teachers' and learners' perceptions of online teaching and learning difficulties and their alternative solutions in the rural school context in Sumbawa Island, West Nusa Tenggara. Indicating and investigating English online classes in rural Junior High schools in Sumbawa is beneficial to decrease the gap of knowledge and skill necessities to students and teachers. In addition, understanding this gap leads the stockholder to make wise decisions to accomplish better online learning. 


\section{Research Method}

This study investigates student and teacher difficulties in English online teaching and learning in junior high school in Sumbawa rural area during the Covid-19 outbreak. This study was a case study. The population of this study involved all students and teachers in rural junior high schools in Sumbawa Island, West Nusa Tenggara Province, Indonesia. The technique of selecting the sample was purposive sampling. There were six participants as the samples. They consisted of four students and four teachers from five different junior high schools. The data was collected through interviews. It took three weeks from selecting participants to conducting the interview. The researchers interviewed the participants in an online way using WhatsApp and the Zoom application. During the interviews, audio and video records were used to record the interview data. The interview was semi-structured.

There were a total of 25 questions which were 13 questions for teachers and 12 questions for students. They had been translated into Indonesian first, and then were checked by the English lecturer to get more acceptable and understandable translated items of questionnaires to be responded to by the students and the teachers. The interview questions were selected and adapted from Abou Naaj et al. (2012), Ratliff (2013) and Dube (2020).

When the date were already gained and prepared, they were transcribed to English analyzed through open coding analysis. As guided by Crosswell (2009), there are generally six steps of analyzing data in qualitative research: (1) Organizing and preparing the data, (2) reading or looking at all of the data, (3) starting coding all of the data, (4) generating a description of the setting or people as well as categories or themes, (5) writing qualitative narrative based on the categories, and the last (6) making an interpretation or theory. In term of coding, open coding analysis is suitable for this study. Strauss and Corbin (1998) as citied in Vollstedt and Rezat (2019) proposed that open coding is a process aimed at identifying concepts or key ideas that are hidden within textual data, which are potentially related to the phenomenon of interest. Firstly, the data were categorized into some 'concepts' that include events, incidents, ideas, actions, perceptions, and interactions of relevance. The second step is similar concepts are grouped into higher order categories. While concepts may be contextspecific, categories tend to be broad and generalizable.

\section{Results and Discussion}

This section reveals the students' and teachers' difficulties in online English teaching and learning during the Covid-19 outbreak and their strategies to cope with the challenges. The participants' responses were quoted using verbatim to provide some emerging codes from the interview result. The interpretation of the findings and the comparison of the previous studies are further explained in the discussion section. The detail of the findings is presented in the table below. 
Table 1. Respondents, Themes, snd Responses from the Coding Process

Respondents Themes Responses

Research Question 1.

Students and Teachers Difficulties in English Online Classroom during Covid-19 Outbreak

\begin{tabular}{|c|c|c|}
\hline R1(S), R2(S), R1(T) & $\begin{array}{l}\text { Technological } \\
\text { Challenge }\end{array}$ & $\begin{array}{l}\text { a) Sometimes we do not have internet quota and not all of us } \\
\text { have a hand phone, laptop, or computer. R1(S) } \\
\text { b) The biggest challenge I've ever faced as a student in an } \\
\text { online class is going to be connectivity problems. R2(S) } \\
\text { c) There is no quota or when I share a link to watch } \\
\text { YouTube they say "can't open it because their quota is } \\
\text { only for opening WA" R1(T) }\end{array}$ \\
\hline R3(S), R1(T), R2(T) & $\begin{array}{l}\text { Social } \\
\text { Challenge }\end{array}$ & $\begin{array}{l}\text { a) The other challenge is that the lack of feeling of bond that } \\
\text { we get from regular school R3(S) } \\
\text { b) In online classes there is less interaction between student } \\
\text { and teacher R1(T) } \\
\text { c) It can't be like studying in a class where we can engage } \\
\text { the students, where we can control their condition R2(T) }\end{array}$ \\
\hline R1(S), R2(S), R3(T) & $\begin{array}{l}\text { Student } \\
\text { Isolation } \\
\text { Challenge }\end{array}$ & $\begin{array}{l}\text { a) I have a problem concentrating in an online class because } \\
\text { I often get sleepy and sometimes even fall asleep on my } \\
\text { table R1(S) }\end{array}$ \\
\hline
\end{tabular}

b) Because maybe I've been sitting at home for a long time, I am bored of studying R2(S)

c) The lack of motivation during the classroom R3(T)

R3(S), R2(T), R1(T)

R3(S), R1(S), R2(T)

R3(T), R2(T), R1(T)
Technological Competency a) To learn English online, there are many challenges, because we have to learn individually and there is no explanation. R3(S)

b) The difficulty is my lack of competence in the IT field to be honest R2(T)

c) They were not familiar with other applications such as Zoom, Google Classroom, so they only used WA R1(T)

a) I also don't think that the results will be as good as that. If I were learning in a regular school. Because again, something about online learning just makes me dizzy and feel dead. R3(S)

b) I want when the teacher gives the material, we don't need to look for other materials so that we don't have any more difficulties in learning and understanding the subject. $\mathrm{R} 1(\mathrm{~S})$

c) There is not enough time to explain, especially during the pandemic which we are only given $2 \times 30$ minutes., $\mathrm{R} 2(\mathrm{~T})$

Pedagogical Challenge

a) I cannot finish all the materials in the textbook R3(T)

b) You must learn how to use Zoom, the IT, how to deal with the network error, and how to innovate the application. We seem monotonous. R2(T)

c) Many of my objectives are not fulfilled because students only see cellphones and assignments R1(T)

Research Question 2.

Students and Teachers Strategies in Dealing with Their Difficulties in English Online Classroom during Covid-19 Outbreak

\begin{tabular}{lll} 
R4(T), R1(S) & Conducting & a) to have a restricted offline class where we can divide the \\
& Blended- & learning into online and offline classes. R4(T) \\
& Learning and & b) teacher will explain when offline class conducted. R1(S) \\
& Offline Class & \\
& Help-Seeking & \\
\hline
\end{tabular}




\begin{tabular}{|c|c|c|}
\hline & $\begin{array}{l}\text { and Family } \\
\text { Support }\end{array}$ & \\
\hline R3(T), R1(S), R1(S) & $\begin{array}{l}\text { Utilising } \\
\text { Various } \\
\text { Resources } \\
\text { Management } \\
\text { and Teaching } \\
\text { Methods }\end{array}$ & $\begin{array}{l}\text { a) The principal takes more responsible for that to inform us, } \\
\text { the teacher. R3(T) } \\
\text { b) Once, if I felt difficult with the subject, I immediately } \\
\text { contacted the teacher and the teacher answered immediately. } \\
\text { R3(S) } \\
\text { c) I'll ask my mom for a hotspot or when it's the deadline for } \\
\text { submitting assignments. R1(S) }\end{array}$ \\
\hline R3(T), R1(S) & $\begin{array}{l}\text { Exchanging } \\
\text { Mobile Data } \\
\text { into Wi-Fi and } \\
\text { Finding Stable } \\
\text { Connection }\end{array}$ & $\begin{array}{l}\text { a) The only thing that I can do during this online learning is } \\
\text { giving them additional materials, like, videos and pictures. } \\
\text { Sometimes I make my own video. R3(T) } \\
\text { b) I tried to use my laptop because if I use laptop the signal is } \\
\text { faster that phone R1(S) }\end{array}$ \\
\hline R3(T), R3(S) & $\begin{array}{l}\text { Outside } \\
\text { Establishing a } \\
\text { Study Group / } \\
\text { Group sharing }\end{array}$ & $\begin{array}{l}\text { a) I usually go out to find an open area where good } \\
\text { connections are there or maybe sometimes, I just go to } \\
\text { school to have Wi-Fi. R3(T) } \\
\text { b) when the connectivity is bad. I switch to data other than } \\
\text { Wi-Fi data works. It consumes a lot in a zoom, but it works } \\
\text { other than that... R3(S) }\end{array}$ \\
\hline & & $\begin{array}{l}\text { a) we usually discuss with the other teacher, and we share } \\
\text { about our problem that we face R } 1(\mathrm{~T}) \\
\text { b) they should visit their friend's house in addition to } \\
\text { gathering, they can study together, so if there is material that } \\
\text { he doesn't understand, he can ask his friends and for } \\
\text { collecting his assignments R } 4(\mathrm{~T})\end{array}$ \\
\hline
\end{tabular}

\section{The Students' and the Teachers' Difficulties in English Online Classroom During} Covid-19 Outbreak

\section{1) Technological Challenge}

This term primarily refers to the availability of devices and internet connectivity. Many students and teachers come from diverse economic backgrounds across the Island of Sumbawa, so that not every student and teacher have a device to be used during the online learning-teaching. Furthermore, many pupils encountered poor connectivity as they stayed in rural areas, and only some stayed in urban areas. R2 described that he was facing problems accessing the link given by his teacher. Similarly, R1 expressed that he has difficulties understanding the subject. R1 (T) also revealed that some students could not open the link she shared because of the lack of internet quota. It depicts that there is inequality between the students and teachers who are from rural and urban areas during online learning-teaching.

From the table above, most students and teachers agree that poor internet connection and lack of devices are the major problems faced in online learning. For example, $\mathrm{R} 1(\mathrm{~S}), \mathrm{R} 2(\mathrm{~S})$, and $\mathrm{R} 1(\mathrm{~T})$ are mentioned as follow:

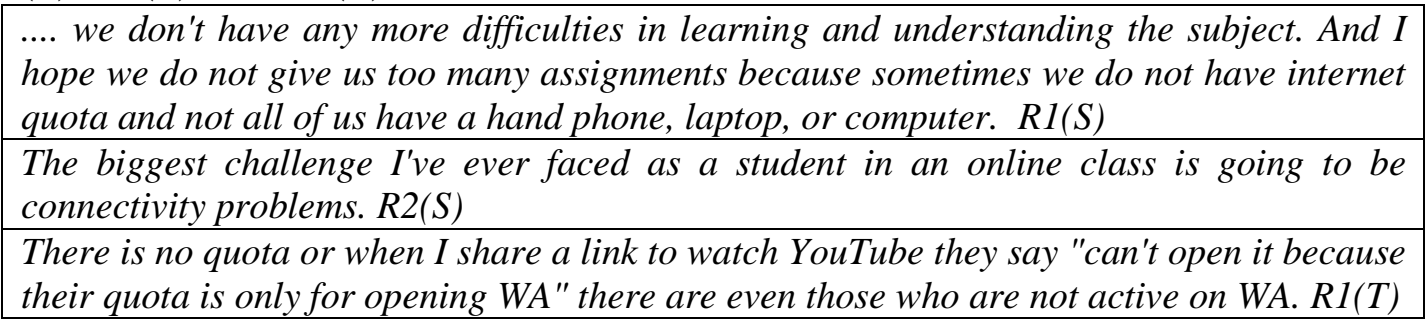


It depicts students who were facing many difficulties engaging themselves due to technological challenges.

\section{2) Social Challenge}

Information technology has its own merits and disadvantages for everyone. Concerning the use of technology in teaching-learning activities, the students are given more opportunities to be independent learners by their teacher studying on his/her own learning. However, it also has disadvantages for both the students and the teachers. They felt that online learning does not provide a genuine feeling or bond compared to face-to-face learning. There is no such real human interaction among the students and the teachers. The interview results indicated it as stated by participants R3(S), R1(T), and $\mathrm{R} 2(\mathrm{~T})$ :

...the other challenge is that the lack of feeling of bond that we get from regular school,
and the slowly rising insanity that I felt every day waking up and then looking at my
phone instead of taking a trip into the school in a car while looking at the environment is
going to be the second biggest challenge. R3(S)
... In online classes there is less interaction between student and teacher... Rl(T)
...when I teach, I always ask them to ask questions, and when I ask for their opinion, they
don't reply, so I'm the only one who is excited in the class group. So, the difficulty is that it
can't be like studying in a class where we can engage the students, where we can control
their condition, but if it's through WA, it's difficult because we just use phone, we don't
know their position is there, whether they're in front of their phone or not... R2(T)

It clearly shows that the students and the teachers have difficulties in dealing with online learning due to the social challenges that they face, and they prefer face to face learning rather than online learning, or perhaps the school might have blended learning just to fulfill the student's desire to interact directly with their teachers and friends.

\section{3) Students Isolation Challenge}

The term refers to the feelings or perceptions perceived by the students when they are learning virtually. In online classes, it is evident that students are demanded to take control of their own learning to maximize the opportunity to be more independent learners. However, they frequently feel discouraged or disinterested during online classes. Indeed, it is hard for the students to maintain their spirit or motivation in the class. They feel bored as they have been undergoing online learning for a pretty long time. This issue was mentioned by the respondent R1(S), R2(S), and R3(T) as follow:

$I$ have a problem concentrating in an online class because I often get sleepy and sometimes even fall asleep on my table, but that's only sometimes, but it's still a big issue. I'm way more concentrated in face-to-face learning than I'll ever be in an online class, that's for sure. $R I(S)$

Because maybe I've been sitting at home for a long time, I am bored of studying. R2(S)

Then the second one is students' interest. I mean, yeah, the lack of motivation during the classroom. $R 3(T)$

Some students feel it difficult to concentrate on online learning because they get bored facing the same situation from the excerpts. Hence it made them have less motivation in learning.

\section{4) Technological Competency}

Another issue stated by the participants is technological literacy and competency. Since the focus of the study is in a rural junior school on the Island of Sumbawa thus, most students and teachers are illiterate or lack IT skills and related things, especially platforms used in online learning, such as Zoom, Google Meet, WA, and others. The 
school and teachers should provide training to the students earlier before commencing online learning. It is conveyed by some of the participants as follow:

To learn English online, there are many challenges, because we have to learn individually
and there is no explanation. R3(S)
For me, the difficulty is my lack of competence in the IT field to be honest. Indeed, we are
old fashioned teachers, the more we learn, the quicker we forget. R2 $(T)$
...not all of them were present, so it was not effective to teach online and to teach online
we only used WA because they were not familiar with other applications such as Zoom,
Google Classroom, so they only used WA and students who joined in WA group only a
dozen students from the number of 20 students. RI (T)

Both students and teachers had difficulties with technology because they were not used to it. They are not like students and teachers in urban areas that use technology as their daily activities to learn.

\section{5) Self-regulation and Learning Comprehension Problem.}

In the implementation of online learning, students often delay their tasks. They also did not prepare themselves prior to the online learning. Besides that, poor management is also a severe issue encountered; for example, when the teachers gave a task, they sometimes exceeded the deadline, even though some did not collect their assignments. Moreover, during the online classes, students felt difficulty understanding the materials their teacher taught. It also resulted in the poor learning achievements of the students.

There were three of the participants who dictated the related statements regarding the issues above:

I also don't think that the results will be as good as that. If I were learning in a regular school. Because again, something about online learning just makes me dizzy and feel dead, compared to the lively environment of my school. That's in my opinion R3(S)

I want when the teacher gives the material, we don't need to look for other materials so that we don't have any more difficulties in learning and understanding the subject. $R I(S)$

there is not enough time to explain, especially during the pandemic which we are only given $2 \times 30$ minutes, ... R2(T)

The students' statements above prove that virtual learning is not adequate for the students. Likewise, R3(S) was not sure about his academic achievement compared to the regular class. Furthermore, the students found it challenging to understand the materials because the time allotment was also insufficient.

\section{6) Pedagogical skills}

Online teaching and learning are not the same as face-to-face learning. The teachers need to be equipped with technology and learning tools in their teaching activities. Furthermore, the approaches or techniques used are also distinct. Hence, the teachers must revise the way they teach in the offline classes to online ones. In Indonesian contexts, primarily for the teachers teaching in rural areas, they experienced difficulties utilizing the online learning platforms. As a result, they lack teaching skills, including poor classroom management, and often lead to the ineffectiveness of the teachinglearning outcomes. Some of the participants denoted:

Yes, correct. I don't think that I have met my expectations because there are still a lot of things that I haven't done in my teaching process, like I cannot finish all of the materials in the textbook. And I'm not sure that the students, I am not sure that my students can communicate using English like they can learn in the classroom. R3(T)

...But in terms of applying online devices, it is a lot of trouble because we must study them first. You must learn how to use Zoom, the IT, how to deal with the network error, and how to innovate the application. We seem monotonous. R2(T) 
...It seems very, very ineffective, first in terms of learning objectives, many of my objectives are not fulfilled because students only see cellphones and assignments. From there, I think their understanding of the material is still lacking because it is only through $W A$, but if offline we can know whether they understand or not, so we can help... Rl(T)

From the inputs above, teachers could not reach their target in objective learning because of some problems that they get in online learning. So, online learning was not effective in rural areas.

The students' and the Teachers' Strategies to Cope with the Difficulties Faced in the English Online Learning

1) Conducting Blended-Learning and Offline Class

Most of the participants' inputs wanted to conduct a hybrid teaching and learn to overcome the problems. R4, as a teacher, denoted that she wanted to hold mixed-mode classes by combining online and offline meetings. She further explained that teachers could assign a task through online classes and then deliver the lesson through an offline class. Similarly, the student, R1(S), perceived the same opinion with the teacher. R4(T), that the solution is that teachers should be conducting offline classes to ensure that the students can easily understand explanations. Their responses are stated below:

....to have a restricted offline class where we can divide the learning into online and offline classes. The task is through online class and the material is through offline class $R 4(T)$

The teacher will explain when offline class conducted. Rl(S)

Thus, it can be concluded that both teachers and students want to have blended learning and go back to the regular class.

2) Help-Seeking and Family Support

Another strategy that most teachers and students stated is seeking help and finding support from the family. Many students sought help when they got difficulties in learning. They mostly asked their teachers, their classmates, or even their families. The student's input, R1(S), described that when she found difficulties in certain subjects, she often contacted her teachers for help immediately. Her teachers also responded to her quickly. They also always have support and motivation to keep motivated in online learning.

Additionally, R1(S) sought support from her parents. She asked for a hotspot when the deadline for her tasks was approaching. Meanwhile, the teacher R3(T) respondent obtained support from his school. He discussed the strategy or solution with his fellow teachers and his school principal to face online classes. Their responses are displayed below:

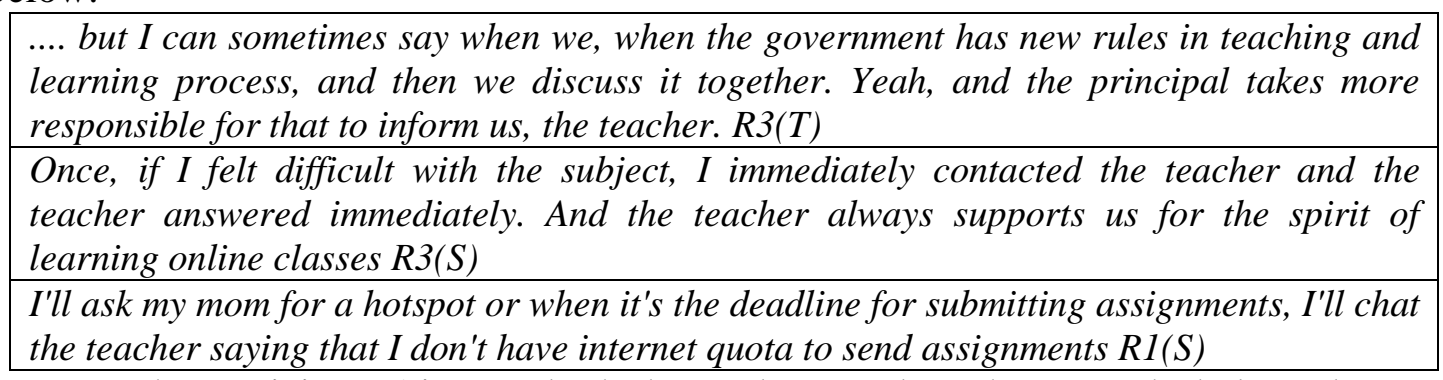

From the participants' inputs, both the students and teachers sought help and support from their surroundings. For example, when the students did not understand the material, she would chat with the teachers to ask some questions, and the teachers not only answered the students' questions but also motivated them. On the other hand, the teacher 
sought support from his school principal and the other teachers to discuss the right solution or strategy used in the online teaching-learning.

3) Utilizing Various Resources Management and Teaching Methods

The other exciting strategy found is that both teachers and students wanted to experience different online teaching methods and platforms used during the teachinglearning activities. By doing so, students and teachers would find more appealing learning tools. As a result, they will be more engaged and motivated to learn. R1 (S) mentioned that switching her learning tool from a smartphone to her laptop was easier and faster. On the other hand, respondent R3(T) remarked that to overcome the students' boredom during the online classes, he often employed various teaching strategies and techniques, such as giving the students additional lessons and material, giving video and pictures. For example, R3(T) and R1(S) denoted that:

...the only thing that I can do during this online learning is giving them additional
materials, like, videos and pictures. Sometimes I make my own video. R3(T)
$\begin{aligned} & \text {.......so, I tried to use my laptop because if I use laptop the signal is faster that phone } \\ & R I(S)\end{aligned}$

The pupil claimed that when she had a bad internet connection, she would use her laptop because, in her experience, using a laptop is faster than a phone. Meanwhile, the teacher tried to utilize the other learning methods using pictures and videos as additional learning materials for the students hoping that the students would understand more about the materials.

\section{4). Exchanging Mobile Data into Wi-Fi and Finding Stable Connection Outside}

To deal with the bad and poor connectivity, the participants tried to exchange the mobile data into Wi-Fi or find a stable connection outside. For example, the students and the teachers went outside or even to school to seek a stable connection. Suppose the teachers and the students encountered difficulty with the connectivity. Meanwhile, the students often switched his/her mobile data into Wi-Fi as well. R3(T) respondent revealed that he usually went to school or out where good connections are available to cope with connection problems. Likewise, R3(S) participant described that he generally utilized his mobile internet data as the solution when he encountered a bad connection. Participants mentioned:

...to solve the problem related to the internet connections of me as a teacher, I usually go
out to find an open area where good connections are there or maybe sometimes, I just go
to school to have Wi-Fi. R3 (T)
One of the solutions I usually use that when the connectivity is bad. I switch to data
other than Wi-Fi data works. It consumes a lot in a zoom, but it works other than that...
$R 3(S)$

\section{5). Establishing a Study Group / Group Sharing}

Finally, the last strategy used by the participants is making study groups or group sharing. Either teacher or student attempted to create a group study whose aim was to share anything related to the teaching and learning activities during the online English learning in the pandemic.

R1(T) Respondent depicts that he often discussed with his fellow teachers the problem he faced, and he tried to come up with solutions. Similarly, R4 respondent's input suggested that when the students have leisure time, they should visit their friends to discuss and study. Moreover, if the students did not understand any materials, he or she could ask his/her friends as well. It is expected as a learning community for the students to assist each other in online learning during the pandemic. Some of the participants said: 


\begin{abstract}
we usually discuss with the other teacher, and we share about our problem that we face, and we face same problem that make us confuse how to solve the problem and we just let it be. $R I(T)$

maybe if they have free time, they should visit their friend's house in addition to gathering, they can study together, so if there is material that he doesn't understand, he can ask his friends and for collecting his assignments, he can ask for help from other friends to accompany him maybe. $R 4(T)$
\end{abstract}

The participants' responses above showed that group sharing and discussion are essential during the English teaching and learning amidst the Covid-19 outbreaks. The participants believed that fellow teachers and classmates are essential to share each other's problems in an online teaching-learning.

\title{
Discussion
}

Based on the analysis and the findings, the concept of online teaching-learning in rural junior high schools in Sumbawa is still unfamiliar for both teachers and students. In this study, there are several challenges that students and teachers faced in online teachinglearning during covid-19, which is in line with the study of Towip, T. et al. (2020); namely, (1) internet data and connectivity issues, (2) a lack of organization and time management, (3) Pedagogical skill and (4) students who were less motivated because of a new learning method. Both the students and teachers (R5 \& R6) found it hard to adapt to the new situation and condition of online teaching and learning. Therefore, they were trying to overcome the new situation by applying online technology for learning. In this study, the students (R1, R2, and R3) mentioned they could not engage in class because they had difficulties obtaining the technology and were more negligible. English as one of the subjects in Junior High School is taught by the WhatsApp and zoom platforms which are less effective for the students to be accommodated in the learning process.

Moreover, there are no devices to accommodate the students for the online course is also another problem. In this study, the students (R1, R2, R3) are less motivated to follow the class because of less technology usage. Thus, the less usage of technology is highlighted by Williams (2016), who emphasized that technology plays a significant role in learning and teaching the English language.

According to Jaques and Salmon (2007), the relevance of comprehending learners and their capacities is equivalent to selecting which technology to use. Likewise, Hassan et al. (2008), the inefficiency of rural Internet exposure is attributable to low rural engagement and a lack of support from the relevant stakeholders. In this study, Students (R1 \& R2) and Teachers (R1) were facing the inequality of internet signal and internet data. Their internet data can only be used for WhatsApp Chat. Students of R1(T) cannot download the documents that were sent through WhatsApp. Students (R2) stated that the most significant issue was connectivity. As a rural area, students come from lower-economy classes; they cannot afford a smartphone in an online class. The provider's signal is the students' and the teachers' issues in conducting the English online class. According to ICT Indicators (2016), people with internet connections in rural and urban regions are 26.3 percent and 48.5 percent. Azali (2007) stated that signals from different operators are unequally distributed. Indonesians have several devices and SIM cards to balance reduced connectivity prices and signal quality. Unstable internet signals are a problem in the process of learning. As the class instructor, teachers are having several issues when they are conducting the online class.

The process of trading knowledge and information with educators and other students is referred to as interaction. As a result, interaction is vital in the growth of learners and has 
an impact on their learning outcomes (Mehall, 2020). In this study, the interaction between students (R3) and teachers (R1 \& R2) is only through gadgets and online. There is no direct interaction between them. Student (R3) stated that another difficulty was her daily routine of only looking at her phone instead of going to school and enjoying the neighborhood with her friends. Moreover, the teachers (R1 \& R2) provided information about how the students gave less attention during the English online learning class. Less direct interaction is a wider gap between the teacher and the student, and the outcomes of this case are less attention from the students and less control from the teacher.

In this study, students (R2 and R3) are unmotivated during the learning process. Isolation and no support from the family make them unmotivated and uninterested in the material or the lesson itself. It is in line with the study done by Inderawati et al. (2019). They conveyed that the engagement of learners was crucial in digital learning. Distractions that students encountered when studying at home influenced the learning process. As a result, low-motivated students should make a more significant effort to stay motivated by recalling their language learning objectives. Teachers may be able to help pupils with low motivation by creating meaningful but enjoyable learning resources.

Both teachers and students utilised several strategies to overcome the challenge in their online teaching-learning. First, instead of fully online classes, it is better to apply the mixed method or blended learning between online and face-to-face classes as mentioned by both the teacher and the student, such as R3(T) and R4(S). Implementing this method decreases the difficulties encountered by the students and the teachers. The second way to strategise the problems is seeking help and assistance either from the colleague or the classmate. Undoubtedly, all the participants stated that they seek help as experienced by R1 and R3 for teachers and R1 and R4 for students.

Moreover, relating to the previous strategy, in this study, both teachers and students that are $\mathrm{R} 1(\mathrm{~T})$ and $\mathrm{R} 4(\mathrm{~T})$ and $\mathrm{R} 1(\mathrm{~S})$ and $\mathrm{R} 4(\mathrm{~S})$, especially to the students who have no gadgets, can make study groups or groups sharing with their friends as a platform for discussing and learning together related to English material. Finally, to deal with the poor connection, either teacher or student might find stable connectivity or even go to school to utilize the school Wi-Fi. These findings have been found in the previous study by Agung, Surtikanti, \& Quinones (2020). They propose that accessibility is still the major factor influencing the success of online learning. Online learning, they said, requires some more friendly platforms so it can increase students' participation. It is mainly for students who reside in rural areas with limited internet connections and other support systems. In addition, participants from the same school, which are R3(T) and R3(S), for example, utilized their school Wi-Fi as an alternative for the unstable connection problem. One of the participants, $\mathrm{R} 4(\mathrm{~S})$, also depicted that online learning is helpful inaccessibility to knowledge and information, despite its unbeneficial. Khan et al. (2021) found that students choose e-learning for the ease with which they may obtain study resources, and the study believes that online learning allows them to learn effectively. Based on that, considering the needs and fixing the regulation is needed as stated by the participants.

Thus, in discussing the recommendation to the policymakers in dealing with the online learning struggle, almost all the participants asked for a better solution from the school, educational ministry, and government, as suggested by a previous study by Khan et al. (2021). They pinned the necessity of creating measures for improving the quality of online learning to help with better learning of students during the phase of the Covid-19 pandemic. The government and related sectors should provide digital access for suburban instructors and pupils and the underprivileged. (Izhar et al., 2021). 
Teaching and learning in an online environment due to the pandemic is formidable. However, EFL teachers and students must be more open, reflective, creative, and adaptive to the rapid changes of technology and circumstances in the education field, particularly in utilizing the technology in the online classroom as seen from their hindrances encountered during the teaching and learning process. Teachers need to equip themselves with instructional design and learning tools to provide more captivating and meaningful learning. They should use professional development activities to upgrade their knowledge on how to integrate technology into language teaching (Son, 2018). Training must be provided to ensure that they are well enough to conduct online classes in times of emergency (Moorhouse, 2020). The students should adjust themselves to be more self-directed learners by maximizing the technology usage to learn better. They should not rely on the teachers; they can learn from others as alternatives to seek assistance on the problems they have.

\section{Conclusion}

The present study contributed to the literature that it provides insight on EFL teachers' and students' perspectives on the challenges and strategies they employed in online teachinglearning amidst the pandemic in a rural area in Indonesia. EFL teachers and students strive to maximize the teaching-learning process through various activities and methods synchronously and asynchronously. However, they still faced challenges in which the learning process is not running well due to connectivity issues, lack of pedagogical competency of the teachers, and limited skills in utilizing the instructional technology. The knowledge gap of technology and less direct interaction often make the students and the teachers unable to provide effective and efficient learning. The teachers should be more prepared and equipped with skills and practices to provide more effective and meaningful learning in online classrooms because distance learning is distinct from face-to-face learning. They must be familiar with some other learning platforms and use different techniques that they can use, including gamification tools and learning management systems.

On the one hand, students should be ready and well-armed with the online learning tools used. They ought to enhance their digital literacy skills as well in using technologyenhanced learning. Also, seeking support from teachers and parents is the ultimate solution when they encounter an issue in the learning process. The findings of this study are expected to enrich the other EFL teachers and students views on the constraints they faced in teachinglearning English online in the time of the pandemic as well as to give new insight for the policymaker or related stakeholder to provide more support for both teachers and students so that the teaching-learning activities will be running more smoothly.

\section{Recommendation}

Future educators need to integrate both synchronous and asynchronous learning to minimize destructive connectivity issues encountered by the students. They also must integrate technology tools in their teaching activities with ICT and technology-enhanced learning to create a meaningful lesson. Future researchers can dig more into the comparative study between the EFL Teachers and students who live in urban and rural areas. More research is also recommended to use a mixed-method and quantitative study regarding the online classroom practices in the EFL or ESL learning contexts. Furthermore, future research could focus on conducting a more in-depth review of the best instructional practices, course design, and technological tools to use and determining whether these practices have helped e-learning students achieve their academic goals. 


\section{References}

Abou Naaj, M., Nachouki, M., Ankit, A. (2012). Evaluating Student Satisfaction with Blended Learning in a Gender-Segregated Environment. Journal of Information Technology Education: Research. 2012;11:185 - 200.

Adedoyin, O. B., \& Soykan, E. (2020). Covid-19 pandemic and online learning: The challenges and opportunities. Interactive Learning Environments. Advance online publication.

Agung, A. S. N., Surtikanti, M. W., \& Quinones, C. A. (2020). Students' perception of online learning during COVID-19 pandemic: A case study on the English students of STKIP Pamane Talino. Jurnal Sosial Dan Humaniora, 10(2), 225-235.

Azali, K. (2017). Indonesia's divided digital economy (pp. 1-12, Working paper ISEAS Perspective No. 70). Singapore: Yusof Ishak Institute.

Cresswell, J. W., (2009). Research Design: Qualitative, Quantitative, and Mixed Method Approaches ( $3^{\text {rd }}$ Edition). California: Sage Publication.

Chun, D., Kern, R., \& Smith, B. (2016). Technology in Language Use, Language Teaching, and Language Learning. The Modern Language Journal, 100, 64-80.

Dube, B. (2020). Rural online learning in the context of COVID 19 in South Africa: Evoking an inclusive education approach. Multidiscipline Journal of Educational Research, Vol. 1 No. 2.

Farrah, M. \& Al-Bakry, G. H. (2020). Online learning for EFL students in Palestinian universities during corona pandemic: Advantages, challenges and solutions. Indonesian Journal of Learning and Instruction, 3(2), 65-78. DOI: https://doi.org/10.25134/ijli.v3i2.3677

Gillett-Swan, Jenna. (2017). The Challenges of Online Learning: Supporting and Engaging the Isolated Learner. Journal of Learning Design 10(1):20.

Hamid, R., Sentryo, I., Hasan, S. (2020). Online learning and its problems in the Covid-19 emergency period. Jurnal Prima Edukasia, 8 (1), page 86-95.

Hassan, M. A., Ismail, N., Omar, S.Z., \& Bolong, J. (2008). Kesan Terhadap Peserta yang Mengikuti Projek ICT di Luar Bandar. Pertanika Journal of Social Science \& Humanities, 16(1), 85-94.

Heng, K., \& Sol, K. (2020). Online learning during COVID-19: Key challenges and suggestions to enhance effectiveness. Cambodian Education Forum.

Inderawati, R., Sofendi, Purnomo, E. M., Vianty, M., Suhendi, D. (2019). Students Engagement in Utilizing Technology for Learning Support. English Franca: Academic Journal of English Language Education, 3(1), 182-196. dx.doi.org/10.29240/ef.v3i02.1111

Izhar, N. A., Na, Y. M. A., \& Na, K. S. (2021). Teaching in the Time of Covid-19: The Challenges Faced By Teachers in Initiating Online Class Sessions. International Journal of Academic Research in Business and Social Sciences, 11(2), 1294-1306

Jaques, D., \& Salmon, G. (2007). Learning in groups: A handbook for face-to-face and online environments. Abingdon, UK: Routledge.

Khan, M. A., Nabi, M. K., Khojah, M., \& Tahir, M. (2021). Students' perception towards elearning during COVID-19 pandemic in India: An empirical study. Journal of Sustainability, 13(1), 57.

MCIT. (2016). Households \& individual ICT indicators. Jakarta: R\&D Center for Post \& ICT Resources, Equipment \& Operation, Research, and Development of Human Resources, Ministry of Communication and Information Technology. 
Mehall, S. (2020). "Purposeful interpersonal interaction in online learning: what is it and how is it measured?", Online Learning, Vol. 24 No. 1, pp. 182-204.

Moorhouse, B. L. (2020). Adaptations to a face-to-face initial teacher education course 'forced' online due to the COVID-19 pandemic. Journal of Education for Teaching, OO(00), 609-611. https://doi.org/10.1080/02607476.2020.1755205

Petrie, C. (2020). Spotlight: Quality education for all during COVID-19 crisis (hundrED Research Report \#01). United Nations. Retrieved from https://hundred.org/en/collections/qualityeducation-for-all-during-coronavirus

Ratliff, K. A., \& Oishi, S. (2013). "Gender differences in implicit self-esteem following a romantic partner's success or failure": Correction to Ratliff and Oishi (2013). Journal of Personality and Social Psychology, 105(5), 889.

Subedi, S., Nayaju, S., Subedi, S., Shah, S. K., \& Shah, J. M. (2020). Impact of e-learning during COVID-19 pandemic among nurshing students and teachers of Nepal. International Journal of Science and Healthcare Research, 5(3), 9.

Son, J.-B. (2018). Technology in English as a Foreign Language (EFL) Teaching. The TESOL Encyclopedia of English Language Teaching, 1-7. https://doi.org/10.1002/9781118784235.eelt0448

Towip, T., Estriyanto, Y., Rohman, N., Suharno, S., \& Pambudi, N. (2020). Vocational PreTeacher Students' Perceptions on Online Learning During Covid-19 Pandemic in Java, Indonesia: Benefits, Challenges, and Suggestions. Indonesian Journal of Informatics Education, 4(2).

UNICEF. (2020, February 25). UNICEF, UNDP, SMERU impact study on the pandemic in disaster-hit areas reveals much vulnerability. Retrieved from https://www.unicef.org/indonesia/press-releases/unicef-undp-smeru-impact-studypandemic-disaster-hit-areas-reveals-vulnerability.

Vollstedt, Maike \& Rezat, Sebastian. (2019). An introduction to grounded theory with a special focus on axial coding and coding paradigm. In: G. Kaiser, N. Presmeg (Eds.), Compedium for early Career Researchers in Mathematics Education. Springer International Publishing, pp. 81-100.

Williams, D. (2016). How an LMS Supports English Language Teaching. Topics: The Learning Platform. Retrieved from https://www.topyx.com/lmsblog/lms-supportsenglish-languageteaching-workplace. 